RESENHA

\title{
Um novo olhar sobre as Teorias da Arte
}

\author{
Beatriz de Barros de Melo e Silva \\ Maria das Graças Vital de Melo \\ Universidade Federal de Pernambuco
}

Anne Cauquelin, doutora e professora emérita de filosofia da Université de Picardié - França, autora do livro Teorias da Arte (tradução Rejane Janowitzer; Martins Fontes, 2005; 177 páginas), inicia seu texto explicando porque usa esse título e não coloca nele o termo estética. Afirma que estética nomeia a área de significação em torno da arte, sendo corpus teórico, espaço de especulações filosóficas, sítio. As teorias, por sua vez, são parte da estética; são discursos sobre a arte. Para a autora, a teoria é de suma importância, considerando que ela é "meio indispensável para a vida das obras". Coloca, ainda, a palavra teoria no plural e defende o termo por compreender encontrar aí a existência de "atividade contínua" que acontece a partir de diferentes autores, defesas e argumentos.

Apresenta como objetivo para o livro a classificação das teorias a partir dos efeitos de seus discursos no próprio domínio da arte, propondo uma "tipologia" no sentido de caracterizar os diferentes gêneros teóricos. Deixa claro também que sua intenção é a distinção de quais discursos trazem impacto sobre a sensibilidade estética, sobre o pensamento do que seja arte e sua produção e do que esses discursos podem representar para artistas e para o público em geral.

O critério, então, usado por ela para a distinção das teorias foi o do gênero de discursos teóricos. A metodologia assumida foi a da caracterização desses gêneros, portanto, sem a preocupação de apresentar as teorias em sequência cronológica. Assim ela classifica as teorias da arte em de fundação e de acompanhamento.

As teorias de fundação são discursos filosóficos gerais que projetam valores, noções e princípios e inscrevem formas de conceber, de sentir e praticar a arte. São reflexões teóricas que não se constituem em uma teoria sistemática a respeito da arte, mas criam ambiência discursiva em direção a ela. Ou seja, são escritos para a arte e não sobre a arte. A autora subdivide as teorias de fundação em ambientais e injuntivas.

As teorias de acompanhamento são discursos elaborados nos espaços de discipli- 
nas já constituídas - como a hermenêutica, a semiótica, dentre outras - ou por pessoas que teorizam práticas - críticos de arte ou os próprios artistas. Buscam compreender e propor explicações a respeito do fenômeno artístico, sejam relativas à significação das obras e dos processos artísticos ou à "organização dos signos por meio dos quais a obra se manifesta”, sejam pela emissão de opiniões de um especialista a respeito da produção de um artista ou pelo registro do próprio artista sobre seu percurso produtivo. A autora subdivide as teorias de acompanhamento em teorizações secundárias e em práticas teorizadas.

O argumento usado por Cauquelin ao longo do livro é o de que os discursos constituem realidades, delimitam e conformam, ajudam a definir e delinear o próprio domínio da arte. O discurso em artes acontece através dos diferentes atores - críticos, artista, público - a partir das opiniões e apreciações de todos os meios culturais, constituindo um "pano de fundo" que ela conceitua como doxa, designação da tradição clássica do conhecimento "de primeiro grau", que acaba constituído pelos lugares-comuns.

Assim, desde o início do livro, a autora procura verificar o lugar da doxa no debate sobre os discursos teóricos da arte, e defende que resguardar esse lugar como rumor teórico nos propiciará a compreensão das nuances entre a recusa e o acolhimento, o "esquecimento ou a glorificação" de produções, de artistas e dos temas da arte.

A autora conclui que a articulação dos discursos teóricos da arte - de arte e para a arte - acontece a partir desse "cimento" que chama de doxa, amálgama dos discursos de arte hoje, "amontoado" que deve ser considerado como rumor teórico, pois forma em torno da arte uma "nuvem de sentido".

Ler o livro Teorias da Arte de Cauquelin nos amplia a reflexão sobre a estética e suas teorias, e nos leva a compreender os discursos que ouvimos/presenciamos sobre a arte. Esses discursos, tratados como rumor teórico, também são imersos em lugares-comuns, "resquícios" de misturas de teorias diversas. Faz-nos reconhecer a doxa e as proposições dóxicas que acabam por compor o próprio sitio da arte, juntando "migalhas de saberes".

Ler este livro de Cauquelin deveria ser obrigatório para professores, estudantes, artistas e críticos de arte, considerando que ele explica e fundamenta os discursos de e para a arte, fazendo-nos identificar aspectos definidores desse domínio de conhecimento. Mas a leitura é fundamental mesmo para professores das linguagens artístico-estéticas por "arrumar", por assim dizer, as percepções, os conceitos, as compreensões sobre a arte. E, principalmente, por nos tornar atentos para os nossos próprios discursos, nossas proposições e encaminhamentos pedagógicos, na observação constante se são 'amontoados' de lugares-comuns, ou se fruto de estudo e olhar mais aprofundado; se discurso para a perpetuação do "achismo" ou para a liberdade e aventura do conhecer. 